\title{
DISCURSOS MÉDICOS, EDUCAÇÃO E CIÊNCIA: ESCOLA E ESCOLARES SOB EXAME
}

MEDICAL DISCOURSES, EDUCATION AND SCIENCE: SCHOOLS AND STUDENTS UNDER EXAMINATION

Maria Stephanou ${ }^{1}$

Resumo Nas primeiras décadas do século XX, no Brasil, uma evidência se impõe: a proliferação de discursos médicos tematizando as relações da medicina com a educação. $\mathrm{O}$ artigo examina discursos médicos que se voltam para a educação, seus múltiplos temas, especialmente dirigidos a examinar os espaços educativos e os escolares, e que destacam que a medicina social preventiva era inconcebível sem a educação. E, inversamente, que a educação era inconcebível sem a incorporação dos avanços da ciência, representada pela medicina. De uma medicina anatômica a uma medicina fisiológica, demonstra como se deslocam a discussão e a missão da medicina, pondo em relevo a educação e o pedagógico propriamente dito. No âmbito do processo de produção de novos saberes e poderes, vê-se instaurado o lugar autorizado do médico para orientar os pedagogos e dotar a educação de teorias e práticas científicas. $\mathrm{O}$ olhar questionador dos médicos sobre a escola e os procedimentos de exames e testes, como demonstrações do alcance da ciência, reafirmam a precariedade da pedagogia e a proeminência da medicina para cuidar e educar crianças e jovens na escola.

Palavras-chave discurso médico; história da educação; educação sanitária; medicina social; Brasil.
Abstract One thing stands out in the first decades of the $20^{\text {th }}$ century: the dissemination of medical discourses addressing the relation between medicine and education. The present article analyzes medical discourses on the many multiple aspects of education. It focuses on discourses that examine schools and students and underline that social preventive medicine would be unattainable without proper education. These discourses also remark that educating would not be possible without the incorporation of advancements accomplished by science - which were, in turn, personified by the medical profession. The article not only shows how the medical science was anatomy-centered and became physiological, but also demonstrates how the discussion and the mission of the medical science and profession started encompassing Education and Pedagogy. In this new paradigm, doctors legitimately guided pedagogists and created scientific theories and practices for education. The questioning looks of doctors over school and the tests and examinations they performed - only to display science's capabilities - confirm the precariousness of pedagogy and the prominence of medicine in caring after children and adolescents in school.

Key words medical discourse; history of education; sanitary education; social medicine, Brazil. 


\section{Medicina e educação}

Os discursos médicos e o campo da educação, ou o processo de medicalização da escola, são temas há alguns anos examinados pela historiografia, particularmente pela historiografia da educação. Propõe-se, neste artigo, fazer girar o caleidoscópio pensando nas composições ilimitadas que ele suscita. Novos fragmentos: discursos médicos que se voltam para a educação. Múltiplos temas educativos, inusitados contornos, minúcias exploradas por um olhar médico que perscrutou o espaço escolar. Intensidade de cores: refrações de uma medicina que, da concepção anatômica à concepção fisiológica, desloca a discussão do pedagógico. Composições simétricas: saberes e poderes que instauram o lugar autorizado do médico para orientar os pedagogos e dotar a educação de teorias e práticas científicas. Dissimetrias: o olhar questionador dos médicos sobre a escola. Arranjos: os procedimentos de exames e testes como demonstrações do alcance da ciência.

Quais são os elementos em destaque nos jogos aqui operados com as posições e figuras do caleidoscópio?

Nas primeiras décadas do século XX, uma evidência se impõe: a proliferação de discursos médicos que tematizam imbricações da medicina com a educação ${ }^{2}$. Tematização que permite demonstrar o quanto os médicos se ocuparam das questões educativas de seu tempo e se empenharam em salientar que a medicina social preventiva era inconcebível sem a educação. E, inversamente, que a educação era inconcebível sem a incorporação dos avanços da ciência, representada pela medicina.

No Brasil, pelo menos desde o final do século XIX, discutia-se que educação e saúde seriam as investidas mais importantes para 'salvar o país' do atraso, da degeneração, da catástrofe. Se o Brasil era um "grande hospital", na expressão do dr. Miguel Pereira ${ }^{3}$, não bastaria atender clínica e terapeuticamente as doenças, uma vez que um dos fatores determinantes neste estado de coisas era a ignorância. Curar implicava, necessariamente, instruir e educar, para prevenir e erradicar as doenças e a ignorância a que o povo estava condenado.

O acompanhamento dos periódicos médicos nacionais das primeiras décadas do século XX indica a afluência significativa de artigos tematizando a educação sanitária, em especial a educação sanitária escolar. Nos periódicos dirigidos ao público em geral, a presença assídua de artigos escritos por médicos, ou a multiplicação discursiva de temas ligados à higiene individual e social, a circulação de informações sobre doenças, a relevância das obras de saneamento, inclusive moral, a importância da participação do povo nas campanhas sanitárias e, muito especialmente - competindo com o prestígio do tema educação escolar -, uma grande atenção à educação das mães, a puericultura, considerando-se que aí residia o enigma da caixa-preta: edu- 
quemos as mães para que eduquem adequadamente os filhos, para que persigam a higiene pré e pós-natal. A denúncia dos altos índices de mortalidade infantil associada à ignorância aparece insistentemente neste período. Também são expressivos, enquanto problemas, o alcoolismo, a sífilis e a tuberculose. Mesmo considerando que muitos artigos ligados à higiene e saúde não são escritos por médicos, sendo alguns, inclusive, traduções de autores clássicos da época, importa pôr em relevo essa proliferação discursiva, em que temas médico-sociais emergem a cada momento.

No movimento do caleidoscópio interessa, particularmente, demonstrar uma certa 'impregnação' do campo pedagógico pelos saberes médicos e, de alguma maneira, a circulação dos saberes pedagógicos, que vinham se delimitando pelo menos desde o século XIX, informando os discursos médicos. Não se trata apenas de discutir a antecedência de um ou de outro, embora em determinados momentos seja possível apontar a preponderância de um sobre outro. O intento é mapear a complexidade das teias discursivas que mostram imbricações desses saberes, médicos e pedagógicos, na modernidade, e que operaram sobre o processo escolar.

\section{Da terapêutica à profilaxia ou de clínicos a higienistas e educadores}

No Brasil, uma evidência se mantém nas primeiras décadas do século XX: os médicos consideraram a escola o locus educativo por excelência, concebendo a educação de jovens e crianças como aquela que produzia os melhores resultados, mais intensos, arraigados ao próprio modo de ser e se portar do indivíduo. Por isso, dirigir às crianças e aos adolescentes a educação, e aos adultos, a assistência.

Embora a educação sanitária devesse ser estendida a todo o corpo social, julgavam que o ensino da higiene seria mais produtivo na escola, pois criaria hábitos, multiplicaria práticas higiências, chegaria às famílias através dos estudantes. A escola emergia, então, como locus irradiador, cumprindo um importante papel social no combate à ignorância e na promoção da saúde. Enquanto espaço institucional, fazia ver o dr. Espírito 4 que seria justamente através de um serviço de higiene escolar que estariam reunidos os dois marcos fundamentais do futuro da nossa gente, daí a grande responsabilidade que pesava sobre os ombros dos que estivessem dedicados aos problemas de saúde e educação (Espírito, 1942a, p. 175).

A referência aos avanços da ciência médica e suas contribuições para dotar a educação de mais eficiência e sintonia com as urgências de seu tempo instala uma efervescência de discussões inéditas em torno da missão educativa da medicina e do estatuto científico da pedagogia. Sugerindo, indiretamente, uma espécie de arcaísmo da pedagogia, de seus métodos e 
resultados, a medicina propunha uma subordinação da pedagogia à higiene, representando esta a supremacia da ciência. Para o dr. Ygartua5,

"A higiene moderna impõe hoje à escola a aplicação do preceito dos antigos latinos: mens sana in corpore sano. A subordinação da pedagogia à higiene é uma conclusão científica inatacável, pois que o médico é o forçoso diretor da saúde da criança e a escola não se concebe se todas suas manifestações não se realizam para manter a integridade fisiológica do escolar" (Mórquio apud Ygartua, 1933a, p. 215).

Qual é a questão que, a propósito da integridade fisiológica, vem a ser colocada? Duas concepções de medicina confrontam-se nas primeiras décadas do século XX: uma concepção 'anatômica' e uma concepção 'fisiológica'. Sinteticamente, a concepção anatômica concebe o corpo como uma congérie de órgãos cujo funcionamento depende estrita e rigorosamente de sua integridade morfológica e estrutural (Pilla, 1938, p. 67) ${ }^{6}$. Neste sentido, a doença constitui-se numa lesão, e curá-la é corrigir esta lesão, recompondo ou substituindo o órgão afetado. A concepção fisiológica, por sua vez, se assenta sobre a idéia de funcionamento do organismo, o dinamismo e a atividade da vida. Se a vida é atividade, a doença nada mais é que um distúrbio funcional. O papel do médico não consiste em tratar da lesão estritamente, mas em corrigir as perturbações funcionais a ela ligadas. Por isso, o organismo, mais que um mecanismo, é um mecanismo vivo (Pilla, 1938). Embora uma concepção não implique, necessariamente, na exclusão da outra, a concepção anatômica persistiu quase absoluta por muito tempo, e foi nas primeiras décadas do século XX que a concepção fisiológica passou a ser preponderante. Entretanto, segundo o dr. Pilla, não se tratava de um antagonismo, pois essas concepções representavam duas fases diferentes da evolução do pensamento científico: da forma à função.

A concepção anatômica, comparando o organismo a uma máquina, concebe a função na dependência estrita da forma e por ela se explica, donde se depreende que todo distúrbio decorre de uma alteração estrutural. Contudo, essa é, nos dizeres do dr. Pilla (1938), uma comparação imperfeita, pois o organismo vivo, sim, é um admirável mecanismo, mas é igualmente um ser organizado, suas diversas partes foram feitas para o todo e o todo depende das partes, havendo uma dependência recíproca. Sendo uma máquina viva, gera-se a si mesmo, mantém-se, dirige e repara. Essa é a diferença fundamental entre as duas concepções. O mais simples dos mecanismos, diz o dr. Pilla, não existe por si mesmo, não se cria a si mesmo. Como tratá-lo isoladamente ou apenas substituí-lo? Ao invés de "ser o funcionamento simples expressão da estrutura, ele é quem a elabora", pois como sugere o aforismo de Lamarck, "a função faz o órgão" (Pilla, 1938, p. 69).

Além disso, graças à unidade do organismo e à interdependência das funções, o funcionamento de um órgão repercute no de todos os outros. Se, 
então, a doença é concebida como essencialmente constituída por distúrbios funcionais, a lesão perde a predominância que possuía na patologia. Um distúrbio pode ser dissipado não obstante a lesão, pela capacidade dinâmica do organismo em restituir suas funções. O organismo não constitui um terreno inerte, mas está repleto de predisposições passageiras ou duradouras e de aptidões funcionais para reagir ou sucumbir aos estados mórbidos.

Acresce ainda o dr. Pilla (1938) que a concepção fisiológica da doença não apresenta apenas um interesse doutrinário; também comporta conseqüências de grande alcance prático, uma vez que abre novos horizontes à medicina preventiva, que passa a incumbir-se da tarefa de corrigir a predisposição mórbida, isto é, combater a doença antes que ela tenha se instalado no organismo, por meio de uma espécie de terapêutica abortiva. Deve-se destacar também que, em se tratando de profilaxia, a concepção fisiológica permitiu ampliar a ação médica percebendo que, assim como o orgânico reage sobre o psíquico, o psíquico influi sobre o orgânico.

Uma nova concepção de medicina, dessa maneira, estendia-se para uma 'leitura' médica dos fenômenos educativos: uma visão fisiológica do escolar, a importância atribuída a todas as atividades funcionais do ser vivo a serem consideradas pela escola - uma educação física, mental, intelectual, moral - , as condições do terreno e as predisposições herdadas ou constituídas pelos processos preventivos e pedagógicos. Além do mais, a concepção fisiológica estende-se para o social e pensa o indivíduo e a coletividade como absolutamente interdependentes: um indivíduo são contribui para uma sociedade sadia e, inversamente, uma sociedade em degeneração produz indivíduos imperfeitos. Daí que a fisiologia tenha vindo a tornar a medicina preventiva, como sugere o dr. Oscar Clark7 , "uma ciência com aplicação individual, isto é, que vela pela educação e criação de cada pessoa" como forma de assegurar a saúde de todos (1931b, p. 398).

Ao transporem a discussão sobre as concepções de medicina do campo médico para o âmbito da educação, embora sem torná-la explícita, é como se os médicos, salientando uma grande mudança na educação provocada pela concepção fisiológica, sugerissem que a pedagogia anterior estivesse assentada numa concepção anatômica dos escolares, que levava ao predomínio da preocupação com lesões isoladas ou com o meio sanitário, já que ele seria responsável por deflagrar as lesões. Essa crítica foi particularmente insistente nas formulações do dr. Clark, cujos trabalhos tiveram ampla circulação nos periódicos médicos nacionais e que, a propósito, referia:

“(...) a medicina preventiva fisiológica salientou a importância de um físico harmônico, em estado de equilíbrio funcional, de imunidade biológica e de perfeita adaptação ao meio. (...) a medicina preventiva fisiológica cria, educa e assiste as pessoas desde o nascimento, para que sejam mantidas em boas condições de saúde" (Clark, 1931b, p. 398, grifos do autor). 
A extensão dos saberes médico-fisiológicos para o campo pedagógico implicou em mudanças mais importantes. Para o dr. Clark, o desenvolvimento da fisiologia teria revolucionado a mentalidade dos profissionais e pedagogos no que respeita à prevenção dos estados mórbidos, à receptividade do organismo para contrair uma doença e, muito em especial, ao culto da educação sanitária física nas escolas. Enfim, com base nos conhecimentos científicos da fisiologia, era possível promover uma séria crítica aos métodos pedagógicos e propor um ensino organizado de modo que, da escola, nenhum dano pudesse advir para o desenvolvimento normal da criança, uma vez que

“É a pedagogia fisiológica, com efeito, que ensina a intercalar o estudo, o repouso, os trabalhos manuais e as diversões para fugir à imobilização da criança na carteira, horas a fio, uma das maiores torturas que se podem infligir ao organismo nessa idade; que vela pelo crescimento normal do aluno mediante a vida ao ar livre, a educação física, o repouso suficiente e ótima alimentação; que recorre aos excitantes fisiológicos do meio externo - ar, sol e água - em contato direto com a pele, para desenvolver as forças naturais de defesa do organismo, (...) que utiliza a piscina, o pátio de recreio, a oficina, a jardinagem, a cozinha e as excursões, como complemento da educação intelectual; em cuja obediência se instituem hábitos higiênicos e o ensino da higiene passou a preocupar tanto a professora, quanto o simples combate ao analfabetismo" (Clark, 1931b, p. 397-398, grifos do autor).

Enfatizando uma espécie de revolução operada pela medicina na mentalidade dos pedagogos, o dr. Ygartua (1933a, p. 212), de sua parte, salientava que os programas eficientes e salutares resultavam de uma organização científica e pedagógica, a exemplo do que ocorria na Alemanha e na Bélgica. Tal destaque ao 'científico informando o pedagógico' é mencionado também por outros médicos, chegando-se mesmo a afirmar, emblematicamente, que

“(...) atraindo a medicina para o meio escolar, adquiriu a pedagogia um aspecto moderno e elevado de proteção à criança, pois, incorporando em seu programa os ensinamentos de higiene, implantando a idéia de saúde, fez mais que defender o indivíduo, pois defende a raça, eugeniza a sociedade e oferece à Nação a energia da saúde geral da população" (Mello, 1937, p. 222).

Se a medicina atribui à pedagogia um aspecto moderno e elevado, impossível compreender na escola a separação entre o médico e o professor na educação das novas gerações ou conceber que a moderna educação não contemplasse a educação sanitária. Para o dr. Fontenelle 8 , essa era uma evidência tão defensável que até mesmo o grande filósofo educacional norte-americano, John Dewey ${ }^{9}$, fixando as diretrizes da moderna educação, afirmava que "a saúde é um dever 
e que organizar a educação higiênica das novas gerações é função precípua da escola de hoje" (Fontenelle, 1932, p. 388).

Dentre os autores da educação citados pelos médicos, Dewey é, indiscutivelmente, o mais referido ${ }^{10}$. Alguns médicos sugerem que as aproximações entre medicina e educação seriam mais fecundas a partir das idéias desse educador. Para Dewey, a educação era concebida como processo de vida, "educação é vida", o que vinha a estabelecer proximidade com a concepção fisiológica da medicina, pautada pela noção de funcionamento do organismo e atividade da vida. Assim sendo, o médico paranaense José Pereira Macedoll (1933, p. 216) defendia que, se educação é vida, ao médico não se poderia negar papel saliente e necessário na escola, pois a necessidade precípua da medicina é justamente velar pela criação. Quem, até então, sempre se ocupara da vida?

Além disso, o dr. Macedo salientava como importante o fato de que, para Dewey, o fim (o resultado) da educação se identifica com os meios (o processo), do mesmo modo que os fins da vida se identificam com o processo de viver, demonstrando mais uma instigante relação com as novas concepções da medicina fisiológica. Neste sentido, indagava o dr. Macedo (1933, p. 215-216), a quem senão ao médico caberia a obra indispensável de pôr em evidência os elementos necessários para a constituição normal de base biológica sobre a qual assenta todo o complexo edifício educativo?

\footnotetext{
“Fosse a educação processo pelo qual a escola super ajunta atributos novos ao ser em evolução que os receberia passivamente de fora para dentro e a tarefa do professor bastaria (...), mas tratando-se do próprio processo de viver, o conhecimento profundo da criança e do adolescente, das suas necessidades psicológicas nos diferentes estádios de desenvolvimento e do meio adequado para o crescimento da base física de cuja integridade depende a evolução concomitante do espírito, os instrumentos educacionais se complicam e a educação não pode prescindir da ação conjunta dos seus fatores essenciais, sobrepujando o médico especializado na vigília constante das condições em que se realiza o processo educativo, sobre a criança, sobre o lar de que procede, sobre o meio escolar e sobre o próprio professor" (Macedo, 1933, p. 217).
}

Da mera transmissão de conteúdos ao entendimento da educação como processo de viver, novas exigências se impuseram. Em especial, aquelas que passaram a requerer dos educadores outro conjunto de conhecimentos, necessários a uma racional atuação pedagógica. Para o dr. Macedo (1933), seria "estultice" almejar reunir em um só indivíduo, o professor, essa soma de saberes para uma moderna educação; legitimava-se a distribuição de competências específicas, sobressaindo-se aquelas do médico escolar, detentor dos conhecimentos científicos necessários para observar, classificar, propor métodos de ensino e, enfim, zelar pela integridade fisiológica dos estudantes. 
"Recusar a colaboração [do médico] é um contra senso que não se justifica, porque além das suas afinidades com o professor na ordem das cogitações mentais em busca e na aplicação das verdades relativas ao bem-estar da humanidade, é ao médico a quem cabe a abnegada missão de velar pela criação e nesse mister ele equivale à própria maternidade, porque se a criação exige ternura e desinteresse, a vida da criação não exige menos, se criar é dar de si nesse desdobramento do próprio ser para a nova vida cuja fonte é o amor, velar pela criação, prolongá-la e aliviar as suas dores é função de bondade cuja fonte é a mesma fonte da vida! Se a educação é a própria vida, ao médico cabe o papel mais importante na educação" (Macedo, 1933, p. 217-218).

Imprescindível e insubstituível no processo educacional, assim referiam os discursos sobre o médico. Sua larga base de conhecimentos nos ramos das ciências concernentes ao processo de viver, ou seja, à educação, e o sacerdócio como imperativo de sua própria tendência psicológica, que o impulsionavam a agir incansavelmente na proteção da infância e na promoção da saúde, legitimavam sua presença no campo educativo (Macedo, 1933).

“Ao invés da prática da arte médica, ao médico nas escolas compete fazer ciência médico-pedagógica que visa essencialmente o desenvolvimento físico e psíquico do aluno, cooperando com o professor para o conhecimento das leis fisiológicas que regem a natureza da criança sob o duplo aspecto somático e mental" (Macedo, 1933, p. 219).

Estavam, dessa forma, explicitados os argumentos para que o campo educativo viesse a acolher como legítimos e pertinentes os postulados da medicina, bem como a inserção de médicos no cotidiano pedagógico da escola. Fundamentalmente, o discurso consistiu em insinuar a preponderância dos saberes médicos para a nova tarefa educativa: mais do que qualquer outro saber, os médicos dominavam as ferramentas cognitivas e metodológicas, seja da biologia, seja da psicologia, para conhecer a criança, decifrar seus sinais, classificar sua capacidade mental, desenvolver seu físico adequadamente e orientar os professores, dotando sua formação de uma consistência teórico-científica reclamada pelo progresso e pelas demandas educativas da sociedade da época. A discursividade médica não deixa dúvidas: a medicina produziu saberes sobre a prática educativa e formulou um determinado projeto de educação.

Entretanto, as interseções entre medicina e educação não implicaram apenas numa extensão dos saberes médicos ao campo educativo. Os próprios médicos registram um outro movimento que vai da educação à medicina. O dr. Clark (193la), por exemplo, observava que, de certa maneira, a higiene escolar findou, por sua prática e sua concepção, influenciando toda 
a medicina, de sorte que esta também foi se modificando. Em que sentido? Considerando a higiene escolar como sinônimo de medicina preventiva, coube à medicina a responsabilidade de cuidar tanto da criança sadia quanto da criança doente. Essa experiência da higiene, atendendo à coletividade escolar, demonstrou a necessidade imperiosa do exame médico preventivo da totalidade dos alunos, para que os males identificados fossem tratados ainda em fase suscetível de cura. A escola, assim, foi um locus fundamental de exercício de uma medicina preventiva em todos os seus aspectos e pôde mostrar os resultados positivos da prática profilática.

“Não conheço serviço que tenha concorrido tanto para mudar a mentalidade do mundo médico e que tenha operado mudança tão radical no exercício da própria medicina. A higiene escolar e o laboratório, com efeito, modificaram a fisionomia da medicina de tal maneira que, hoje, em lugar de o doente procurar o médico, muitas vezes, é este quem, pelos exames periódicos de saúde, vai descobrir a doença nas pessoas aparentemente sadias" (Clark, 1931a, p. 268).

De outra parte, o dr. Gonçalves Vianna ${ }^{12}$, em 1933, reconhecia que, apesar de alguns conhecimentos que a medicina já dispunha sobre os atributos psicológicos da criança, a prática da higiene escolar oportunizara uma intensa observação das crianças escolarizadas, atestando a fonte preciosa de ensinamentos que a escola representava aos médicos. Essa presença médica nas escolas teria efetivamente produzido novos saberes para a medicina.

“É citada a ignorância que se tinha a respeito do desenvolvimento mental e das diferentes condutas, por isto pesquisas foram feitas e obtiveram resultados impressionantes, que revelaram coisas profundas de grande significação, daí acentua-se o valor da 'Pedagogia' como em 'Higiene Mental'. Agora há um respeito pela personalidade do aluno, contrário a outrora onde a repressão e o constrangimento se davam, fazendo com que alguns de caráter forte se rebelassem... O professor tem a meta de estudar cada aluno, avaliar cada um, para posteriormente poder ajudá-los, orientando-os, procurando sublimar os instintos, principalmente quando se mostram dominados. Esta noção do respeito à personalidade tem de ser a idéia mestra de toda a intervenção educadora ou terapêutica" (Vianna apud Ygartua, 1933d, p. 5).

Da mesma forma que ao pedagogo competia apropriar-se dos conhecimentos científicos da biologia e da psicologia para compreender a criança e qualificar sua tarefa educativa, o médico na escola não exercia simplesmente medicina, mas constituía-se como educador. Ora, para o bom desenvolvimento de tão elevada função, além do preparo médico especializado, também cumpria ao médico possuir dotes de espírito que permitissem abranger 
filosoficamente o conjunto das ciências relacionadas com a pedagogia. Dessa forma - e considerando que a formação médica não contemplava o ensino da medicina escolar -, de cada médico dependia um trabalho contínuo de pesquisa e estudo dos vários ramos concernentes à natureza da criança e aos objetivos da educação (Macedo, 1933, p. 220).

Embora sejam escassas as referências explícitas à incorporação de saberes propriamente pedagógicos, o acompanhamento dessa discursividade no tempo permite perceber um refinamento da discussão médico-educativa, uma atenção maior a processos muito particulares da escola, como os mecanismos da aprendizagem, além do emprego de um vocabulário concernente à pedagogia - exemplificado pelas expressões 'ensino ativo', 'pedagogia moderna', 'educador/educando', 'educação como processo do viver' - que se disseminou no discurso médico.

Uma outra questão sobre as aproximações entre medicina e estatuto científico da pedagogia: Foucault, em Vigiar e punir, assinala que a disseminação da prática do exame na escola possibilitou uma intensa circulação de saberes; o mestre transmitindo-os a seus alunos e, através dos exames, levantando um campo de conhecimentos sobre esses mesmos alunos. Isso fez com que a escola se constituísse em local de elaboração de uma pedagogia, espécie de liberação epistemológica do pedagógico. E, portanto, para Foucault, a era da escola examinatória marcou o início de uma pedagogia que funciona como ciência (1993, p. 166). Ora, aqui caberia indagar sobre a decisiva presença dos médicos na escola, inaugurando muitas vezes uma outra ordem de exames - os testes cognitivos, o controle do desenvolvimento antropométrico -, particularmente por meio das inspeções médicosanitárias, contribuindo ativamente para a produção dos saberes pedagógicos. Indiscutivelmente, a produção de conhecimentos da pedagogia deve muito aos conhecimentos psicofisiológicos produzidos e aprofundados pela atuação médica nas escolas. Isto pode ser brevemente atestado pela crescente incorporação desses saberes em disciplinas específicas da formação de professores na Escola Normal, por exemplo, insistindo-se para que fossem ministradas por médicos escolares, bem como pela manutenção, em nossos dias, de testes incorporados ao cotidiano escolar pela ação médica.

\section{O discurso científico para a escola}

Uma relativa ambigüidade parece caracterizar o discurso médico sobre educação dos anos 1900 até fins da década de 1940. De uma parte, como vimos anteriormente, o destaque à escola como locus educativo por excelência. De outra, ácidas críticas dirigidas aos métodos e procedimentos de ensino, a teorias pedagógicas, à precária formação dos professores e 
mesmo às condições inadequadas do meio escolar. Embora reforçando o caráter estratégico da educação, os discursos médicos buscam desqualificar a prática educativa vigente para fazer reconhecer outras proposições e outros sujeitos. A disputa pela 'verdade' da pedagogia levou os médicos a apontarem sua inconsistente sustentação científica, propondo um campo teórico-prático para dotá-la da cientificidade reclamada.

A escola demandava reformas urgentes e uma indiscutível atuação médico-científica. As críticas à instituição escolar tenderam à universalização; são muito pontuais as referências a uma escola em particular, tendendo a mostrar, portanto, a necessidade de mudanças em todas as escolas.

“É preciso insistir na explicitação das críticas à escola para demonstrar como os médicos buscaram constituir um discurso autorizado e legítimo para as intervenções naquela instituição. Neste sentido, invariavelmente, as questões levantadas pelos médicos se assentavam no caráter científico que presidia suas análises. Desde a crítica aos currículos, passando pelos métodos e processos escolares, até o procedimento de classificação dos estudantes, os argumentos que justificam as discordâncias e aqueles que sustentam as proposições, tratam de explicitar sua base científica" (Stephanou, 2005, p. 151).

Desse modo, as críticas se dirigiam enfaticamente às práticas de classificação e seriação das crianças e jovens na escola segundo o uso do 'falso' critério da idade, uma vez que não havia sustentação pedagógica para tal. Seria, portanto, mais eficiente se os pedagogos dominassem os modernos testes, contribuições da psicologia experimental para a identificação da 'capacidade mental' de cada aluno, decorrendo deste novo olhar outros agrupamentos para a aprendizagem, assentados em bases científicas. Isso implicava a necessidade de formação de professores para levar em conta rigorosa os atributos psicológicos da criança, suas condições de aproveitamento e sua vocação para o exercício profissional futuro (Ygartua, 1933a, p. 217). A inexatidão ou o arcaísmo dos métodos de classificação dos escolares, assim, subestimava ou superestimava capacidades das crianças e dos jovens frente às tarefas, exigências e exercícios físicos ou intelectuais ministrados pela escola, com danos muitas vezes irreparáveis. Essa inadequação dos métodos e procedimentos escolares decorria, basicamente, da uniformização imposta pelo professor, que de outra maneira não sabia agir (Stephanou, 2005).

\footnotetext{
"Programas uniformes e ensinos em conjunto, sem prévio exame das capacidades, é um absurdo que já levou alguém à irônica referência de 'águias e jumentos' obrigados ao mesmo passo, principalmente agora que os modernos educadores já distinguiram a idade cronológica da idade mental dos alunos" (Pitta Pinheiro, 1930, p. 125) 13. $^{13}$
} 
A ausência da prática de exames médicos minuciosos denunciava, ainda, segundo os médicos, a insuficiência da atenção às capacidades mentais dos escolares, pois não detectava patologias, estados mórbidos, psicopatias, representando perigo à coletividade escolar. Diante disso, propunham uma exame meticuloso das crianças que ingressavam na escola.

“Olhemos para uma aula primária e logo nos chamará atenção a heterogeneidade da mesma. Numa promiscuidade psico-fisiológica, aberrando contra toda a pedagogia hodierna, deparamos com os mais variados tipos de crianças que se possa imaginar. Ao lado do tipo normal, do hígido morfo-fisio-psíquicopedagógico, encontramos os tipos infra e super normais. Ao lado da criança sadia, se senta a tuberculosa, ao lado da carregada pelos estigmas da lues está aquele que traduz nos seus traços fisionômicos o selo indelével do alcoolismo. Em face do eutrófico, que vende saúde, está o hipotrófico a exigir, num brado que condói, os necessários alimentos para manter uma vida que baqueia. Contrastando com um retardado pedagógico, está o super-normal, assombrando seus companheiros. Em face de um anormal escolar, vemos o tipo perfeito, de pleno acordo com todos os requisitos da psico-pedagogia moderna" (González, 1934, p. 184-185).

Nas palavras do dr. González ${ }^{14}$, uma espécie de promiscuidade psicofisiológica verificável nas escolas ameaçava as capacidades intelectuais do escolar, como também sua saúde física e mental. As diferentes caracterizações expostas, o hipotrófico, o eutrófico, o retardado, o supernormal e outros, assinalam caracteres que supõem o domínio de conhecimentos complexos e sofisticados que, evidentemente, os pedagogos não dominavam. Reclamavase, então, a participação do médico na seleção, classificação e exame periódico dos escolares. É interessante como o dr. González aludia serem suas observações nada mais que a enumeração de defeitos conhecidos por todos os médicos que discutiam a matéria educativa.

Na seqüência de sua exposição, o dr. González sugeria que a Sociedade de Medicina de Porto Alegre examinasse a proposta de solicitar aos poderes competentes a criação de um Instituto Médico Escolar a fim de proceder à seleção prévia das crianças, em idade escolar, de acordo com os últimos quesitos da psicopedagogia moderna, prática que, segundo o médico, constituía “o ideal de um povo civilizado, embora parecendo irrealizável entre nós" (González, 1934, p. 186).

Essa posição de condenação da prática pedagógica de classificação dos escolares foi sistematicamente objeto de elaboração discursiva dos médicos, que recorriam a exemplos ilustrativos dos graves problemas existentes nas escolas, seja quanto à educação intelectual ou à educação física. 


\begin{abstract}
“Basta recordarmos a nossa vida colegial para avivarmos em perspectiva má, quadros que a memória com fidelidade e vigor reproduz, até mesmo em seus detalhes. Por certo nos acordaremos daqueles que irmanados conosco por uma mesma geração, de nós se afastavam pela tristeza apática em que se achavam sempre mergulhados, e pela fraqueza física que os humilhava, tornando-os mais pálidos e cabisbaixos. Eram os vulneráveis ou tarados, sujeitos a um mesmo sistema uniforme de cultura intelectual e física; portadores de agentes mórbidos ou predispostos orgânicos, pelo grão ou pelo terreno, eram os predestinados a constituir os inválidos do futuro, cujo destino havia de levá-los à condição tristíssima de povoadores dos hospitais, dos sanatórios e das casas de saúde" (Larbeck, 1916, p. 42).
\end{abstract}

Os métodos e processos de ensino foram, igualmente, alvo de críticas severas e, além da uniformização, que comprometia a atenção aos diferentes caracteres e capacidades dos escolares, assinalavam outras contrariedades que constituíam, em seu conjunto, uma situação a que diversos médicos aludiam como o "martírio da escola" (Macedo, 1932a, p. 107). São recorrentes formulações como: "atulhar o cérebro das crianças com coisas abstratas e sem nenhuma aplicação na vida prática" (Clark, 1930, p. 61); cansar a atenção infantil com recomendações abstratas, incompreensíveis pelos infantes, perdendo tempo (Macedo, 1932a, p. 107); metáforas que representavam a escola como "instrumento de tortura e meio de deformação" (Macedo, 1933, p. 220); “condenar os adolescentes a uma imobilidade prolongada, a um trabalho intelectual intenso agravado, periodicamente, pelos esforços de exames" (Lupi, 1939, p. 163); a proeminência dada pelos sistemas educativos ao desenvolvimento intelectual, em detrimento da higidez física; a prática da memorização de fórmulas áridas, regras e definições, sem interesse imediato, desperdiçando energias da criança em atividades estéreis; ou, finalmente, a afirmação de que a escola arrebata a "liberdade para pô-la no torniquete que a pedagogia moderna e a higiene escolar se esforçam por afrouxar" (Macedo, 1933, p. 222)15.

Os professores, agentes por excelência da missão educativa, eram avaliados por médicos que se detinham em examinar os estabelecimentos escolares. Referiam-se às imperfeições da formação dos professores, pois desconheciam a realidade psicofisiológica do 'ser criança', como identificá-la e, assim, viam-se limitados em suas ações, sendo incapazes de escolher um tipo de ginástica, desporto ou atividade intelectual de acordo com as necessidades e possibilidades de cada estudante. Daí que usavam a mesma medida educativa para todos os ânimos infantis e juvenis. Como assegurar a formação do caráter e da inteligência nessas condições?

Os médicos, por sua parte, embasados nos conhecimentos científicos, sabiam como 'conhecer'16 a criança, perceber se suas condições de saúde eram adequadas à convivência escolar. Se a escola devia constituir-se em 
agremiação sadia para não colocar em risco o escolar hígido, então procediam os exames para admissão, que deviam surpreender os doentes antes do ingresso na escola, barrar seu acesso e encaminhá-los a instituições de assistência. Era preciso também conhecer a criança durante sua freqüência à escola, acompanhando a escolarização, os efeitos provocados pelos exercícios intelectuais, pela prática dos desportos, pelas exigências da ordem e da disciplina, o que muitos professores desconheciam. Surpreender os instáveis e os fatigáveis. Identificar ainda os diversos estados constitucionais, adequando cada indivíduo a atividades concernentes às suas capacidades e a estímulos específicos. Surpreender os retardados ou tardios. Urgia igualmente localizar aqueles alunos com defeitos psicomorais perniciosos nas relações entre os escolares. Surpreender os psicopatas e desajustados. Ei-nos novamente nas taxionomias, complexas, inacessíveis sem a ciência. Elas foram constantemente redefinidas, saberes produzidos pelas astúcias da observação, pelo refinamento dos procedimentos científicos, pela extensão dos exames criados e aplicados.

“As qualidades do observador, o valioso auxílio da clínica, da radiologia e das reações tuberculínicas, são armas poderosas para selecionar o escolar infectado e ele será classificado, sob o ponto de vista médico, pedagógico e social" (Ygartua, 1933a, p. 224).

O poder do médico de dizer a verdade de cada um vai sendo endossado na coletividade escolar. As famílias consultam os médicos nas escolas, os professores perseguem conselhos daquele que pode lhes dizer sobre os alunos problema, as crianças habituam-se a se submeter a exames médicos periódicos, em nome da profilaxia. Os médicos são reconhecidos como aqueles que, descobrindo, podem curar, salvar, corrigir, conduzir pelo procedimento mais adequado, ensinar aos professores como manejar e, finalmente, premiar com o diagnóstico de saudável e normal. Espécie de pastor que deseja o melhor para seu rebanho (Foucault, 1990, p. 101).

Outra direção dos questionamentos chamava atenção para o espaço e a materialidade das escolas. Os preceitos da higiene, ignorados ou desprezados pelos professores e diretores escolares, e de domínio dos médicos, faziam realçar a insalubridade, a inadequada localização dos prédios, a falta de planejamento racional das salas de aula, onde avultavam problemas de iluminação, ventilação, inadequação do mobiliário e dos equipamentos, passando ainda pelos bebedouros, refeitórios, pátios, sanitários, alertando acerca dos prejuízos físicos e morais aos alunos, como os problemas de visão, os focos de contágio, os distúrbios posturais e danos à coluna, dentre outros.

De outra parte, criticando o fato de que, muitas vezes, as escolas contentavam-se em "ensinar a ler, a assinar o nome e a contar bolinhas", não 
havendo o ensino de hábitos de asseio, para salvaguarda da saúde (Lentino, 1930, p. 64), os discursos médicos questionavam o próprio currículo escolar, as incumbências da escola, os ensinamentos ministrados, salientando o absurdo de que a higiene ainda não fosse objeto de ensino, embora figurassem tantos assuntos abstratos e estéreis naquela que era, para muitos, a única oportunidade de aquisição de conhecimentos e modos educados (Stephanou, 2005, p. 153).

O dr. Lentino era mais contundente em sua crítica, chegando mesmo a questionar o valor de uma instrução que excluísse os conhecimentos de higiene, pois, para ele, não era raro encontrarem-se pessoas instruídas que, no entanto, desprezavam os mais comezinhos preceitos higiênicos, porque não os conheciam (Lentino, 1930, p. 65).

Para o dr. Ygartua, as reformas educacionais dos anos 30 não haviam produzido mudanças substanciais, uma vez que métodos didáticos, exames e direção persistiam distantes e divorciados da própria lei do desenvolvimento das faculdades intelectuais e volitivas da infância (Ygartua, 1933b, p. 3).

Classificação e distribuição dos escolares, formação dos professores, espaço e materialidade das escolas, exercícios escolares e conhecimentos ministrados constituem temas que foram investidos de críticas constantes na discursividade médica da época, mesmo quando crescentemente reconhecida a complexidade dos sistemas educativos. Para o dr. Macedo (1932c), a insensatez e o otimismo exacerbados de alguns pedagogos não contribuíam para a modernização das escolas, embora não discordasse da pedagogia nova que propunha o ensino centrado no interesse espontâneo da criança. Mas, para o médico, estaria sempre a escola a exigir da criança o cumprimento de deveres de que estão desobrigadas no lar ou no recreio, o que constituía um erro. Em conseqüência, impunha distinguir a escola como preparação para a vida e a escola como reflexo da vida, aspecto desconhecido dos educadores. Argumentava que nos países desenvolvidos e modernos, onde a vida obedecia a uma lógica econômica e cívica, de bem-estar e de higiene, aí sim a escola poderia ser o espelho da vida. Diferentemente, onde essas condições inexistiam, a escola deveria começar por "ser a própria vida, porque do refleti-la somente, como de fato reflete, tal como ela existe em nosso país, outro proveito não colheremos que o de reforçar hábitos que ainda mais nos amesquinham" (Macedo, 1932c, p. 232). Entretanto,

“(...) que a escola continue como preparação para a vida na execução dos programas de ensino, dentro da aula, na instrução em suma, mas que seja ao menos no recreio a própria vida no evoluir físico e moral do futuro homem desde já integrado no meio social pela coordenação racional da sua exuberante atividade na expansão da sua alegria para a felicidade humana que é afinal o máximo objetivo da educação" (Macedo, 1932c, p.232). 
Para tanto, era imprescindível a colaboração do médico, de modo a aproveitar os intervalos nos trabalhos escolares, instantes preciosos para imprimir na criança, em sua personalidade em formação, "normas racionais de conduta nascidas espontaneamente na consciência infantil pela força persuasiva da satisfação que a prática de atos sadios soem proporcionar" (Macedo, 1932c, p. 233). Dessa forma, nem tudo havia de ser espontâneo na escola. À escola competia

“(...) intervir, sacudida pela força que for, venha donde vier, do governo, das autoridades do ensino, do próprio professor, de instituições ou mesmo de simples particulares e procurar viver a vida cuja projeção no meio doméstico condicione um rumo novo tendente ao aproveitamento do considerável potencial de energia moral e física da nossa gente" (Macedo, 1932c, p.232).

Paralelamente às críticas à educação escolar de seus dias, cabe assinalar que os médicos dedicaram-se também à formulação de propostas de superação do estado de coisas que construíam discursivamente, estando atentos aos questionamentos gerais e específicos que lançavam. Prescreveram modos de organizar os escolares, proposições de ensino, modelos ideais de ambientes educativos, disseminação diversificada de informações que visavam a instruir.

De certa maneira, os comentários tecidos até aqui indiciam práticas discursivas que exprimem o refinamento das problematizações do campo médico sobre a educação no período analisado, ora detendo-se sobre o processo pedagógico propriamente dito, ora examinando e argumentando favorável ou desfavoravelmente sobre as teorias pedagógicas em voga. Importa ressaltar que as discussões sobre educação efetivamente ocuparam a atenção de diversos médicos, associações e congressos da área, não podendo ser menosprezadas no âmbito da medicina social.

Em novos movimentos do caleidoscópio, procuro trazer à tona a densidade dos discursos médicos sobre a escola, discutindo o que diziam, prescreviam e como pensavam sua própria inserção no espaço escolar.

\section{Escolas, médicos e exames: o primado da ciência}

A demonstração da importância dos saberes científicos para a educação, saberes, segundo os discursos médicos, ausentes na pedagogia, consistiu na atuação direta dos médicos como educadores. Tratava-se de realizar uma obra completa - médico-social e pedagógica - nas escolas, o que foi possível através da assistência médica aos escolares, da inspeção, dos serviços de higiene escolar, da inclusão curricular de conteúdos de higiene e educação sanitária, além da prática dos exames médicos, propiciadores de pesquisas 
sobre os escolares, e da aplicação de classificações embasadas nos mais modernos métodos das ciências. Paulatinamente, delimitou-se um regime de saberes e poderes que instauraram a figura do 'médico nas escolas', aquele que deveria ter o domínio do conjunto das ciências relacionadas com a pedagogia, fosse ele pediatra ou higienista, e estivesse diretamente inserido em práticas educativas escolares. Uma das formas da presença do médico e de seu aporte científico foi a prática dos exames.

Débeis, retardados ou tardios, imbecis, instáveis, emotivos, tímidos, deprimidos, tarados, desconfiados, perversos, fatigáveis, neuropatas e psicopatas, desajustados, desatentos, hipostênicos, adenoideanos, abúlicos, precoces, entre muitas outras designações ${ }^{17}$ - onde estaria, afinal, a criança? E a criança normal, teria resistido em algum recanto protegido da escola?

Difícil identificá-la nos discursos médicos. Encontramo-la apenas caracterizada pelos avessos. Numa taxionomia tão ampla e detalhada, restava muito pouco para que a criança não fosse enquadrada nos caracteres de uma gama variada de anormalidades descritas. Se resistisse à inclusão, seria, paradoxalmente, uma exceção à regra, o desvio dos desvios... e, talvez, nesse caso, pela inobservância das taxionomias que fazem parecer que prevalecem os anormais, ao invés de uma penalidade, essa criança fosse premiada com a classificação de 'normal'. Não se trata de mero jogo de palavras. O acompanhamento da discursividade médica permite dar visibilidade à criança problema, o escolar desajustado, o infante anormal, parecendo, por vezes, minimamente entrever a criança sadia. Ou será apenas uma multiplicação discursiva? O efeito indica a prevalência de classificações precisas, próprias de uma concepção de ciência como verdade superior - seja quanto ao desenvolvimento físico e intelectual, seja quanto ao comportamento moral e mental, ou ainda, ao aproveitamento escolar -, classificações que estigmatizam a criança, estabelecem critérios de inclusão e exclusão e findam por estabelecer uma situação prosaica, mas nem por isso menos trágica: até que se prove o contrário, a criança é suspeita, precisa demonstrar que é normal.

Os exames médicos perscrutam a criança escolar minuciosamente. Na família, na sala de aula, no pátio da escola, na história de seus progenitores e antepassados, nos meandros de seu inconsciente e nas profundezas de sua alma. Identificar imperfeições orgânicas, muitas delas com reflexos intelectuais ou mentais, hábitos ou práticas viciosas, anomalias, taras morais, inferioridade física ou psíquica, heranças mórbidas, estados predisponentes, patologias latentes, eis o pano de fundo desses exames e um conjunto de designações próprias à ciência médica da época. O intuito? Surpreender a tempo de apartar dos demais, tratar, prevenir. Os médicos apresentam-se como vigias que, dominando um horizonte mais amplo da ciência, vêem aparecer mais precocemente os signos precursores de uma doença (Barrán, 1995, p. 258). 
A julgar pelos discursos apresentados podemos perceber que a prática do exame médico na escola, ou a aplicação dos testes pelos médicos, caracteriza a instituição escolar como "observatório da multiplicidade humana" (Foucault, 1993, p. 153). Mecanismos disciplinares, tecnologias individualizantes: proporcionar uma visibilidade geral de todos e de cada um. Afinal, como dizia o dr. Figueiredo, os maiores fatores desfavoráveis em profilaxia escolar residem no indivíduo e pouco se aproveitam as inspeções em conjunto sem o exame, o registro e a prescrição individuais (Figueiredo, 1933, p. 3).

Qual o campo de saber e a ordem de poder que os exames científicos permitiram levantar? Uma multiplicidade de questões era suscitada e legitimava os exames médicos.

Como referimos anteriormente, além de 'surpreender a tempo', outros enunciados se voltaram para os exames, pois estes possibilitavam tanto "afastar para evitar a promiscuidade entre sadios e doentes ou para reconduzir os anormais a outras instituições", quanto para "classificar e agrupar". O dr. Espírito sintetizava esses aspectos afirmando que deveriam ser considerados anormais aqueles escolares que não pudessem fazer o aprendizado nos estabelecimentos comuns de ensino e que necessitassem de recursos educativos que só estabelecimentos especiais podiam empregar (Espírito, 1942b, p. 166). Os exames permitiriam afastar os inconvenientes, organizando aulas com turmas homogêneas; para esta finalidade empregavam-se testes de escolaridade (p. 165).

As modalidades de exame foram variadas e transformaram-se no decorrer do tempo. Podiam ser clínicos, antropométricos, intelectuais, psicológicos, além de testes para avaliação do nível global de desenvolvimento da inteligência, testes para determinação de aptidões especiais, testes de escolaridade ou média de eficiência de aprendizagem; testes para avaliação do temperamento e qualidades morais (Ygartua, 1933a, p. 226), tipologias e especificidades que reafirmavam a legitimidade dos médicos, formados cientificamente, e a incapacidade dos professores, sem formação científica. Assim, como afirmava o dr. Pitta Pinheiro, os testes representavam o esforço médico de não se reduzir a um empirismo educacional (Pitta Pinheiro, 1944, p. 53), criticando a pedagogia em comparação ao estatuto científico da medicina.

Os exames clínicos por ocasião das visitas constituíram, inicialmente, a primeira relação dos médicos com os escolares. Investigavam os atributos físicos em seus pormenores, observando com igual atenção as condições de higiene, as aptidões de visão e audição, bem como a possível 'latência' ou suscetibilidade a alguma moléstia contagiosa. Através das avaliações antropométricas, por sua vez, procuravam estabelecer as condições físicas da criança, tomando-lhe para estudo o talhe, o peso e o perímetro toráxico, informações a serem minuciosamente registradas em ficha adequada (Ygar- 
tua, 1933a, p. 227). As pesquisas psicofisiológicas da época punham em evidência as relações íntimas entre desenvolvimento físico e desenvolvimento intelectual da criança.

Florêncio Ygartua propunha que, através dos exames clínicos, os escolares pudessem ser classificados de acordo com seus diversos estados constitucionais. Através dos tipos, além da classificação, a criança seria conhecida, seriam esclarecidas todas as suspeições que sobre ela pairassem e, enfim, o médico poderia conduzi-la para o melhor tratamento, para a turma correspondente, para os exercícios intelectuais e físicos adequados. Esses estados constitucionais estavam relacionados com o temperamento e o caráter de cada criança, por isso sua importância fundamental nos processos pedagógicos. Podemos supor que do laboratório de observações em que se constituía a escola, emergia o traçado de uma semiologia dos distúrbios da criança escolar. O estudo das constituições era o desafio da biotipologia, cujos 'tipos' na infância permitiam vislumbrar os delineamentos da idade adulta. O dr. Ygartua demonstrava especial interesse pela "moderna orientação" oferecida através da classificação biotipológica, examinada no livro de Berardinelli18, muito embora manifestasse inspiração também em Nicola Pende ${ }^{19}$, que, aliás, criara a designação biotipologia para exprimir a ciência das constituições, temperamentos e caracteres. Por constituição entendia-se

“(...) a resultante morfológica, fisiológica e psicológica, variável de indivíduo a indivíduo, das propriedades de todos os elementos celulares e humorais do corpo e também de sua combinação em um tipo especial de composição corpórea (...). Tal resultante é essencialmente determinada pelas leis da hereditariedade e acessoriamente pelas ações perturbadoras exercidas pelo ambiente sobre a atuação do plano hereditário de organização do indivíduo" (Pende apud Ygartua, 1933a, p. 218).

Observe-se, assim, que o estudo biotipológico toma como indícios potenciais para definir o temperamento e o caráter de um indivíduo sua forma corpórea. Para explicitar esse ponto, o dr. Ygartua evocava idéias desenvolvidas pelo dr. Mariante, igualmente interessado nas proposições de Pende, para quem o biótipo podia ser representado graficamente, como sendo o ápice de uma pirâmide quadrangular cuja base é formada pelos elementos hereditários e atávicos e as quatro faces, respectivamente, pelo hábito morfológico, pelo temperamento dinâmico-humoral, pelo caráter e pela inteligência de cada indivíduo. O dr. Ygartua procurava mostrar como, a partir de sua leitura e interpretação, os tipos de Pende e outros biótipos podiam ser considerados no escolar, de maneira a identificar anormalidades ou corrigir possíveis desvios. Sobressaía a caracterização inicial a partir da face morfológica, isto é, física. Uma extensa taxionomia aparecia então, e o dr. Ygartua procurava explicitá-la em sua tese sobre o médico nas escolas ${ }^{20}$. 
Citava também Berardinelli, que resumia as diversas denominações dadas pelas diferentes escolas da biotipologia aos atributos físicos:

“O brevilíneo, megalosplancnico, braquítipo (Viola), corresponde ao hiperestênico (W. Mills), ao pícnico (Kretschner), ao tipo arredondado rond (Mac-Auliffe), ao tipo lateral (Stockard e Bean), ao tipo largo, braquimorfo, ao tipo euriplástico (Bouank), ao tipo conectivo (Virenius), à $3^{\mathrm{a}}$ combinação (Bárbara), à $2^{\mathrm{a}}$ combinação anatômica (Benecke), à $3^{a}$ combinação morfológica (De Giovanni), ao tipo digestivo e ao tipo muscular (Sigaud), ao tipo abdominal (Hallé), ao tipo digestivo (Rostan) ao habitus apoplecticus. O longilíneo, microsplancnico, longitipo (Viola), corresponde ao astênico (W. Mills), ao leptosômico (Kretschner), ao tipo delgado plat (Mac-Auliffe), ao tipo linear (Stockard e Bean), ao tipo longo, dolicomorfo, ao tipo estenoplástico (Bounak), ao tipo epitelial (Virenius), à $1^{a}$ combinação (Barbára), à $1^{\text {a }}$ combinação anatômica (Benecke), à $1^{\text {a }}$ combinação morfológica (De Giovanni), ao tipo respiratório e ao tipo cerebral (Sigaud), tipo toráxico (Hallé), ao tipo respiratório (Rostan), ao tipo ftísicus" (Ygartua,1933a, p. 219-220).

Procede assinalar, além da variedade de classificações, a recorrência a diversos autores que na época circulavam entre os médicos, dando conta da efervescência dos estudos em torno da biotipologia no campo da medicina, com extensão, por exemplo, ao âmbito da criminologia, por meio da teoria da conformação craniana de Lombroso ${ }^{21}$.

\section{Figura 1}

As combinações de De Giovanni para classificação dos escolares

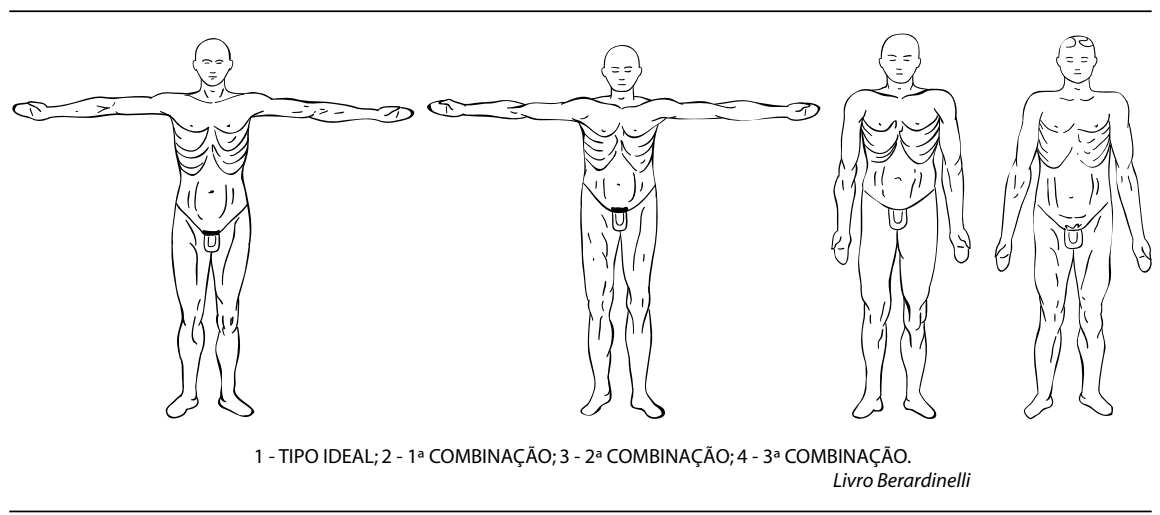

Fonte: YGARTUA, Florêncio. 1933a. O médico nas escolas. Revista dos Cursos, v. 19, n. 19, p. 219 

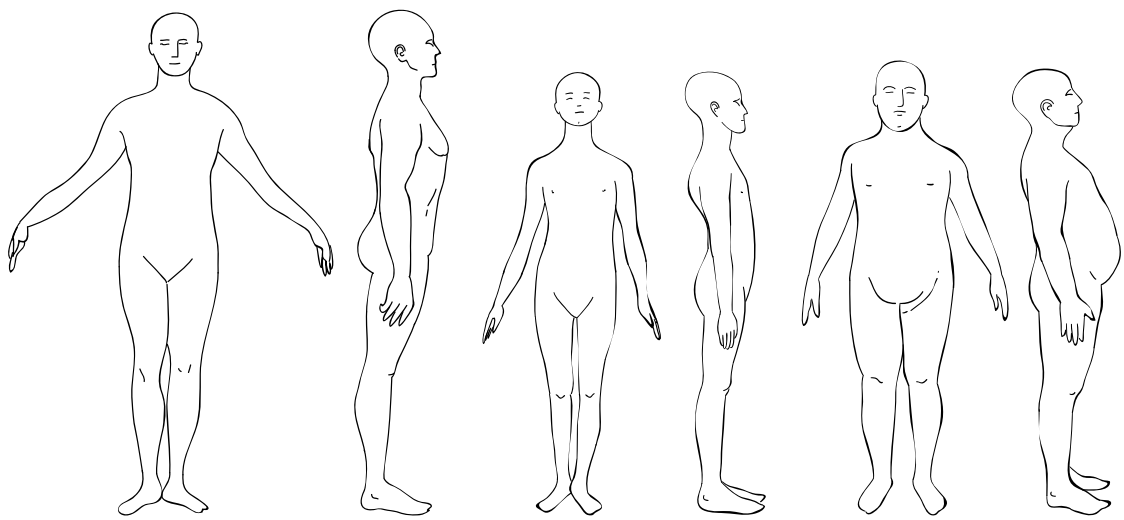

1 - NORMOTIPO (de frente); 2 - NORMOTIPO (de perfil); 3 - TIPO MICROSPLANCHNICO-LONGILÍNEO (de frente); 4 - TIPO MICROSPLANCHNICO-LONGILÍNEO (de perfil); 5 - TIPO MEGALOSPLANCHNICO-BREVILÍNEO (de frente); 6 TIPO MEGALOSPLANCHNICO-BREVILÍNEO (de perfil).

Livro Berardinelli

Fonte: YGARTUA, Florêncio. 1933a. O médico nas escolas. Revista dos Cursos, v. 19, n. 19, p. 219

Mas o dr. Ygartua não se detinha apenas nas aproximações resumidas por Berardinelli. Preocupava-se em considerar os atributos das distintas idades do escolar, o que corresponderia aos períodos admitidos por Pende, a saber:

“ $3^{\circ}$ período: proceritas prima, dos 5 aos 7 anos, marcado pela primeira crise de alongamento, quando o corpo se alonga e afina, com um certo emagrecimento normal. Mais do que aumento ponderal é uma fase que se caracteriza pela diferenciação morfológica, já se notando alguns atributos sexuais; $4^{\circ}$ período: turgor secundus, dos 8 aos 11 anos no homem e dos 8 aos 9 anos na mulher, caracteriza-se por um novo período de desenvolvimento em largura. No homem, o alargamento do tórax, enquanto na mulher a bacia é que se alarga; $5^{\circ}$ período: proceritas secunda, dos 12 aos 15 anos no homem e dos 10 ou 11 anos na mulher, caracteriza-se pela crise da adolescência propriamente dita, ocorrendo um rápido e brusco crescimento em altura, com acentuação dos atributos morfológicos sexuais e modificações mais significativas humorais e neuropsíquicas. Ou ainda, os tipos indicados por Sigaud: $1^{\circ}$ ) tipo respiratório (predomínio do tórax e andar médio da face); $2^{\circ}$ ) tipo digestivo (cabeça em pirâmide; predomínio do abdômen e andar inferior da face); $3^{\circ}$ ) tipo muscular (tronco igualmente repartido entre tórax e abdômen; andares da face iguais); $4^{\circ}$ ) tipo cerebral (predominância do crânio; cabeça em forma de peão)" (Pende apud Ygartua, 1933a, p. 220-221). 


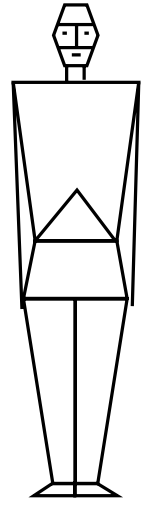

1

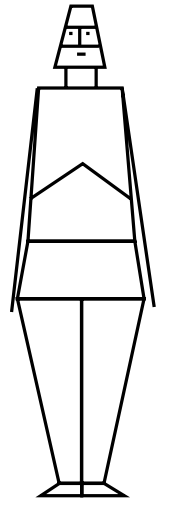

2
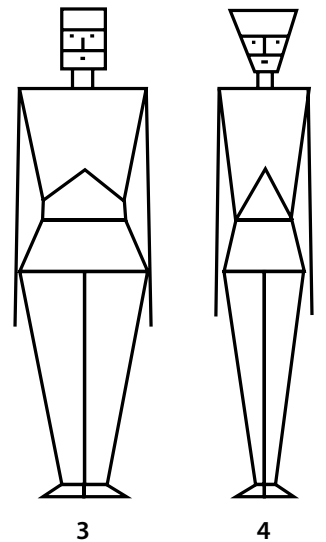

Fonte: YGARTUA, Florêncio. 1933a. O médico nas escolas. Revista dos Cursos, v. 19, n. 19, p. 219

A partir dos tipos exemplificados anteriormente e dos modelos classificatórios que eles forneciam como critérios para a elaboração dos testes ou das descrições e enquadramentos, interessa pensar como esses exames médicos na escola assumiram a feição de procedimentos de identificação, assimilação ou descrição das individualidades e em que medida eles passaram a constituir uma espécie de norma, pela crescente explicitação de um conjunto de especificidades corporais, temperamentais e de caráter, com o intuito de caracterizar as aptidões de cada um, situando seu nível e suas capacidades; cada indivíduo um caso inserido num sistema de diferenciações e hierarquias (Foucault, 1993, p. 163171). Ou ainda, cabe considerar como os exames médico-escolares instituíram um mecanismo disciplinar de individualização, que na escala escolar demonstra seu caráter 'descendente' assentado na fiscalização, na observação, nas medidas comparativas tendo uma norma como referência, seja ela a biotipologia de Pende, Sigaud, Benecke, Viola, Bárbara ou De Giovanni, dentre outros. O que está em jogo é o fato de que a instituição dos biótipos tenha sido usada como parâmetro que associava cada criança a determinados desvios da normalidade, parâmetro assentado na ciência, desconhecido da pedagogia e operacionalizado pelos médicos-educadores. Não será nos consultórios ou hospitais que as crianças serão submetidas a tantas vigilâncias e a tantos exames.

“É a escola o lugar de eleição, o principal campo de observação em que o psicopediatra poderá agir, com eficiência, no sentido do rastrear, de pronto, os sinais reveladores dos pequenos neuropatas, fazendo, por assim dizer, a chamada triagem ou seleção dos anormais psíquicos" (Castilho, 1928, p. 38, grifo do autor). 
Se os exames clínicos foram particularmente fecundos para as classificações biotipológicas, podiam também surpreender as doenças nefastas já incipientes nos infantes ou causas desconhecidas de seus distúrbios, como a sífilis, a tuberculose e a herança alcoólica.

\begin{abstract}
“Consideremos agora o terreno heredo sifilítico e a sífilis com as suas funestas conseqüências para muitas crianças que na escola pagam caro tributo. Como sabemos, a sífilis enche um enorme capítulo da patologia infantil, com seus estados distróficos gerais e locais, muito principalmente no terreno das distrofias endócrinas, diminuindo ou anulando a capacidade intelectual. Cortejo sombrio de surdos-mudos, cegos, idiotas, imbecis, atrasados mentais, muitos deles, não tem o humano direito de se educar na escola" (Ygartua, 1933a, p. 221-222).
\end{abstract}

Restituir aos escolares e a outras crianças possuidoras de anomalias da afetividade e do caráter, assim como aos enfermos do organismo físico, o desejável e o possível equilíbrio orgânico e funcional e rastrear os que apresentavam anormalidades, os psicopatas verdadeiros, que exigiam tratamento mais rigoroso em ambientes especiais (Kaseff apud Moreira, 1935, p. 125), eram propósitos claramente formulados no decorrer dos anos 30 e demandavam, além dos exames clínicos, um conjunto de exames psicológicos elaborados e altamente ritualizados. Essa ritualização progressivamente se afirmava através de um conjunto de registros detalhados e minuciosos, em fichas individuais com anotações diversas que fixavam uma classificação a cada criança.

Os exames psicológicos da criança possibilitavam estudar seu desenvolvimento mental e sua modalidade de inteligência, sendo que eram apresentados como realmente necessários, pois se constatava uma relativa freqüência do anormal entre os escolares, demandando uma atenção especial do médico e do psicólogo (Ygartua, 1933a, p. 224).

O dr. Raul Moreira, conhecido pediatra gaúcho que desenvolveu estudos sobre a criança escolar, sugeria a classificação apresentada por Lahy e Heuyer para distinguir as diferentes categorias de escolares, a saber: a) os débeis mentais e os retardados, que exibem os seguintes grupos: atrasados escolares por incapacidade intelectual; atrasados devido a causa orgânica; e retardados por motivo de ordem social; b) as crianças de inteligência normal, abrangendo os subgrupos: instáveis que mudam constantemente de lugar, parecem geralmente distraídos e freqüentemente se mostram agitados; emotivos, que são tímidos, respondem em voz baixa e com facilidade choram; deprimidos, geralmente tristes, que não brincam, conversam pouco e se comprazem no isolamento; e espíritos falsos, desconfiados e invejosos, que tudo levam a mal e se queixam de tudo e de todos, e perversos, que mentem e se apoderam do que não lhes pertence, fazem o mal pelo mal e permanecem indiferentes à repre- 
ensão e aos castigos; c) os bem-dotados, dos seguintes tipos: os que mostram particular inclinação para certas matérias e deficiência de compreensão para as demais e os fatigáveis, incapazes de esforço prolongado; d) as crianças normais, que não são classificáveis em nenhuma das categorias precedentes, mas para as quais o professor reconhece a necessidade do exame clínico-psiquiátrico (Kaseff apud Moreira, 1935, p. 125).

Além do procedimento da observação, os exames foram se tornando mais elaborados, e se instituíram os testes, especialmente importantes para a caracterização das faculdades mentais das crianças, tarefa primordial no contexto escolar para a qual os professores não recebiam formação suficiente.

Com respeito aos testes intelectuais, fortes indícios levam a crer que, acima de qualquer outro procedimento, aí foram produzidos novos saberes no campo da medicina e a contribuição dos médicos escolares foi decisiva para uma consolidação desse poder na instituição escolar. Saberes até então desconhecidos da medicina, atestados pelo reconhecimento que os discursos expressam quanto à imprescindível colaboração entre médico e professores. Se, em determinados momentos, os professores apareciam como opositores, porque refratários às inovações científicas, em outros, reconhecia-se neles um saber, bem como a necessidade de apreendê-lo.

Embora admitindo um relativo desconhecimento médico das anormalidades sob o ponto de vista pedagógico, os exames e testes asseguravam os saberes científicos da medicina e possibilitavam verificar as anomalias intelectuais que permitiram distinguir grupos diversos de escolares, segundo o grau de comprometimento das faculdades intelectuais mensurado sob os aspectos da atenção, memória, associação de idéias, julgamento, etc. Observe-se que já emergiam critérios de ordem pedagógico-cognitiva integrados ao funcionamento do discurso médico. Evocando uma epígrafe bastante sugestiva de Hippius, o dr. Moreira salientava que:

"Se os médicos reclamam, e com razão, dos educadores e mestres o estudo da fisiologia e da psicologia, ao menos nos seus elementos, é justo exigir que também o médico seja pedagogo" (Hippius apud Moreira, 1933b, p. 3).

Tal evocação indica, de certa maneira, a emergência de demandas, no âmbito da medicina, mais voltadas ao pedagógico propriamente dito, o que pode explicar a produção de classificações tomando por base as manifestações intelectuais ou cognitivo-comportamentais das crianças no espaço escolar. Numa classificação bastante elementar, caracterizavam-se os escolares anormais segundo a idiotia, a imbecilidade e a debilidade mental em relação às condições de aprendizagem (Baptista apud Ygartua, 1933a). Interessante é que, para uma classificação mais elaborada, o dr. Ygartua recorria à caracterização de alunos anormais, sistematizada e expressa justamente por um 
professor. Em seu estudo "A proteção à infância e à juventude", o professor Thiago M. Wurth ${ }^{22}$ (apud Ygartua, 1933a, p. 225) listava os principais tipos de anormais pedagógicos, descrevendo-os como se segue: a) a criança fisicamente fraca demais para acompanhar as outras crianças da mesma idade na sua evolução ou educação física e no esforço físico necessário para a atividade mental; b) a criança fraca de memória, de retenção diminuta ou inconstante, de atenção instável, de concentração mental difícil, de coordenações lentas e inexatas; c) a criança de vida física anormal, muito emotiva, muito imaginativa, ora sonhadora e inerte, ora indisciplinada e superativa. O professor conhece os casos como arteiros, preguiçosos, indisciplinados, retardados ou atrasados, instáveis de gênio, instáveis de atenção e concentração. Ele conhece também os vadios, os mentirosos, os brigões, os chorões, os mimosos e os descurados; e d) os anormais sociais da educação, que não dão resultados normais porque o ambiente de proveniência, a falta de roupa, de alimentação, de tratamento clínico, de educação moral, e outros motivos mais, desvirtuam a ação educadora ou porque nem subsiste para eles ação educativa nenhuma.

Para que possamos ter idéia da extensão da prática médica que concorreu para caracterizar uma "era examinatória" (Foucault, 1993) da escola, é possível identificar outras tantas classificações dos escolares segundo critérios que levam em conta performances de aprendizagem, em última instância o que se concebia como rendimento social da criança. O dr. Castilho descrevia quatro grupos distintos: raras crianças superiormente formadas, capazes de 'ingerir' todas as matérias de um programa; grupo muito mais numeroso dos escolares que assimilavam uma parte das matérias ensinadas e deixavam de lado uma outra parte que deles exigia maior esforço de compreensão - aqueles que 'poderiam fazer melhor'; na cauda da classe, encontrava-se o importante grupo dos preguiçosos, hipoproséxicos ou abúlicos, que revelavam, nas suas anomalias, um verdadeiro 'desarranjo' da saúde, quer física, quer mental, ligado ou a distúrbios endócrinos, a desordens sensoriais ou a leves graus de perturbações nervosas; e os hipernormais, também chamados 'inteligentes brilhantes', de grande precocidade, cuja evolução ulterior, pela 'anormalidade' psíquica revelada, não condizia com as promissoras esperanças dos primeiros triunfos (Castilho, 1928, p. 40-41).

Percebe-se o estabelecimento de relações comportamentais diversas, que por vezes indicam uma arbitrária associação entre atitudes escolares, como por exemplo o cumprimento de tarefas num nível estritamente mínimo, ou resistência a atividades propostas - os preguiçosos -, que são insuficientes para mensurar os graus de desenvolvimento cognitivo, mas que findam reduzidas a eles, sentenciando aos alunos anormalidades e estados patológicos. De certa maneira, muito mais que critérios ditos científicos, parecem prevalecer avaliações morais e disciplinares. 
Efetivamente, o discurso médico dos anos 20 e 30 reconhecia que, apesar dos estudos científicos e das primeiras classificações produzidas, não dispunha ainda de resultados que satisfizessem as premências da escola no que tange aos anormais escolares do ponto de vista educativo. Admitia, ainda, que na escola primária havia um numeroso contingente de alunos que demonstravam incapacidade ou dificuldades de distinto grau para aprender de acordo com os métodos didáticos comuns, enquanto que fora da escola não pareciam insuficientes, o que era instigante para investigações.

Registravam também aqueles que conseguiam apreender as noções que constituíam os programas das escolas comuns, porém num tempo mais longo que o normal, pelo que se lhes chamavam 'tardios', 'retardados'. Alguns, depois de um período crítico de duração distinta, colocavam-se a par dos normais e até conseguiam dar continuidade aos estudos secundários e superiores; outros, pelo contrário, depois de um período de aproveitamento que lhes custava mais ou menos fadiga, detinham-se definitivamente no curso escolar, incapazes de continuar os estudos, e viam-se obrigados a se conformar, revelando nas suas ocupações habilidade e perspicácia; e, por último, existiam outros que uniam uma capacidade escassa para utilizar seu próprio patrimônio ideativo, freqüentemente com decadência progressiva das aptidões intelectuais (Estapé23 apud Ygartua, 1933a, p. 225-226).

Em certos momentos, para afastar inconvenientes, buscou-se organizar aulas com turmas uniformes, com os mesmos atributos psicológicos e intelectuais, independentes do critério falso da idade, aos quais deviam corresponder métodos pedagógicos adequados, para cuja finalidade tiveram incremento o emprego de 'testes' de escolaridade. Os médicos indicavam as dificuldades de elaboração e aplicação dos testes, seja por eles próprios, seja pelos professores, visto que as faculdades mentais (memória, atenção, vontade, etc.) que condicionam o aproveitamento escolar eram consideradas de difícil mensuração, além do fato de que os processos de apuração e diagnóstico nem sempre se encontravam isentos de falhas (Espírito, 1942b, p. 165).

Se um tão extenso detalhamento dos diferentes escolares no discurso médico vem a demonstrar a intensidade dos procedimentos individualizantes, que estabeleciam sobre as crianças uma visibilidade até então desconhecida, de outra parte estavam os médicos a criticar a precariedade das condutas pedagógicas, que tratavam a todos indiferenciadamente, cometendo-se equívocos largamente apontados, ora debilitando os mais frágeis, ora tornando medíocres os capazes acima da média, ora mantendo em penúria educativa aqueles que careciam de tratamento especial.

Alguns médicos propuseram a criação de cursos de biopsicologia infantil para professores, médicos e educadores; outros defenderam a necessidade de ensinamentos de psicologia infantil obrigatórios nos currículos das escolas complementares. 
Para que se pudessem abranger todos os casos de crianças problema, de tão variada natureza e que ainda se complicavam pela associação de múltiplos fatores, alguns médicos desposavam a opinião de que era necessário pleitear a criação de clínicas de higiene mental, ou clínicas de eufrenia24, gabinetes de neuropsiquiatria infantil, psicoclínicas escolares que dotariam o serviço de higiene escolar de maior cientificidade a fim de auferirem melhores resultados, com instalações médicas apropriadas e pessoal técnico especializado, inclusive visitadoras que verificariam nos domicílios dos alunos as informações de cada caso e ministrariam os conselhos indicados aos pais.

Para o dr. Pitta Pinheiro (1944), se a educação progredia em seus objetivos, com sua técnica sempre melhorando, isso se devia tanto aos interessados e estudiosos por seu progresso quanto às suas relações com a medicina, que por meio da psiquiatria oferecia mais amplos e mais seguros meios de educação. Complementando essa idéia, o dr. Pitta considerava que, através dos estudos da eufrenia, outra compreensão e outro tratamento podiam ser dispensados às crianças problemáticas das escolas, compreendendo-se sua evolução psíquica e sua conduta individual. Defendia a criação de "gabinetes de neuropsiquiatria infantil", acordes com os ensinamentos da higiene, úteis para inventariar muitas e imprescindíveis informações elucidativas da vida do menor, no contato com as educadoras, com as professoras, umas em relação com a vida doméstica e outras com a psíquica, informações cada vez mais precisas pela prática e cada vez mais úteis ao julgamento da natureza psíquica do educando (Pitta Pinheiro, 1944, p. 53).

O aprimoramento dos exames e testes fez-se acompanhar da formalização dos diagnósticos e resultados, instituindo-se os registros individuais, através de fichas médico-psicológicas. O procedimento de descrição contemplado nas fichas 'antropopedagógicas' assegurava que a inspeção sistemática dos alunos e o registro de qualquer anomalia física ou mental se constituíssem em meio de controle e vigilância dos escolares.

Circularam, nos anos 30 e 40, propostas de criação de cadernetas de saúde, de que constaria um sucinto registro sanitário com o fito de acompanhar o aluno desde seu ingresso na escola até o fim do curso escolar, fixando-se assim sua história médica (Espírito, 1940, p. 173). Mas, dentre essas proposições, parece ter sido mais difundida e efetivamente implantada a prática das fichas individuais sob guarda dos médicos ou da administração escolar. As fichas contemplavam registros de investigações dos antecedentes da criança, exames clínicos, neuropsicológicos, informações baseadas em testes, observações colhidas pelo professor.

Qual o sentido da produção de tantas classificações, anormalidades e distúrbios a enquadrar os escolares, atando-os à diferença de suas individualidades e delimitando os desvios? Teriam sido, como sugere Foucault (1993), apenas para fazê-los desaparecer, seja pela exclusão dos muito doen- 
tes ou 'perigosos', seja pela ação eficaz da terapêutica médica e dos dispositivos de correção que estariam, assim, legitimados? Há, indiscutivelmente, a partir das múltiplas taxionomias de classificação, a possibilidade de estabelecer campos de comparação, espaços de diferenciação e contornos de uma norma a partir dos quais práticas médicas e pedagógicas assumem novos significados e orientações. Quanto a isso a discursividade médica do período examinado foi particularmente insistente. Já não era admissível uma ação educativa indiferenciada e uniforme a todos, sem a incorporação dos avanços da ciência.

Era preciso produzir um novo conhecimento da criança escolar. Subsumir os escolares em métodos de ensino e parâmetros de avaliação homogêneos era o mesmo que ignorar por completo seu rendimento social e perder o controle dos resultados do processo de escolarização. Poderoso discurso que atesta sua permanência, em um ou outro paradigma pedagógico e em variadas práticas educativas da atualidade, demonstrando-se, assim, que muitas delas, quase imperceptíveis, podem ter tido sua emergência na produção médico-educativa das primeiras décadas do século XX.

De certa maneira, quase inusitada, as classificações das crianças, identificadas e registradas pelos dispositivos médico-pedagógicos, permitem esboçar um registro detalhado e minucioso da escola e dos escolares das primeiras décadas do século. Poucos estudos em História da Educação perscrutam nesses discursos indícios para a reconstrução dos processos de escolarização, problemas de (in)disciplina, diferenças culturais e cognitivas dos alunos de uma mesma escola, modos de pensar e agir dos professores relativamente ao ato de ensinar, mesclas peculiares de códigos médicos e pedagógicos orientando as práticas - enfim, críticas formuladas pelos contemporâneos aos procedimentos educativos vigentes. Críticas que dão conta de mostrar olhares sobre a escola produzidos por outros sujeitos que não apenas professores, administradores públicos, políticos ou representantes do campo religioso, mais comumente apresentados pela historiografia da educação.

Assim, os discursos médicos não explicitam apenas, como se tornou recorrente afirmar, um projeto de higienização genérico. Eles também registram uma leitura médica da escola e operam produtivamente sobre os desafios colocados à higiene escolar pelo exercício de relações conflituosas ou interativas entre pais, professores, alunos, médicos e instituição escolar. Por isso, a discursividade médica pode ser rica para uma cartografia da escola das primeiras décadas do século XX e dos saberes mobilizados nessa instituição. 
Notas

1 Professora do Programa de Pós-Graduação em Educação e do Departamento de Ensino e Currículo da Faculdade de Educação da Universidade Federal do Rio Grande do Sul (Faced/UFRGS). Doutora em Educação pela UFRGS. <mariast@terra.com.br>

2 Essa proliferação não se circunscreveu a uma região do país e pode ser identificada em documentos relativos ao Rio Grande do Sul, Paraná, São Paulo, Rio de Janeiro e Bahia, especialmente nos periódicos: A Folha Médica (RJ), Brazil Médico (RJ), Arquivos Brasileiros de Medicina (órgão da Faculdade Nacional de Medicina da Universidade do Brasil, RJ), Jornal de Pediatria (RJ), Revista Brasileira de Medicina (RJ), Revista Médica do Paraná, Revista Médica da Bahia, Arquivos Rio-Grandenses de Medicina, Anais da Faculdade de Medicina de Porto Alegre, Revista Médica do Rio Grande do Sul, Revista dos Cursos da Faculdade de Medicina de Porto Alegre, Arquivos do Departamento Estadual de Saúde (RS), O Arquivo Médico.

3 Denúncia do médico e professor da Faculdade de Medicina do Rio de Janeiro, em 1916 (Lima e Hochman, 1996, p. 24).

4 Poli Marcelino Espírito foi inspetor médico-escolar, chefe do Serviço de Higiene Escolar do Departamento Estadual de Saúde do Rio Grande do Sul.

${ }^{5}$ Florêncio Ygartua nasceu no Uruguai, em 1892, vindo a falecer em Porto Alegre, em 1941. Estudou na Faculdade de Medicina de Porto Alegre, diplomando-se em Farmácia em 1911 e em Medicina em 1923 e especializando-se em Pediatria. Livre-docente da cadeira de Clínica Pediátrica e Higiene Infantil da Faculdade de Medicina de Porto Alegre. Em 1925, desenvolveu estudos e pesquisas no Uruguai, onde foi discípulo do professor dr. Luís Mórquio. Membro da Sociedade de Medicina e Cirurgia, Rio de Janeiro; da Sociedade de Medicina, Porto Alegre; da Sociedade Brasileira de Pediatria; e do Rotary Club de Porto Alegre. Tomou parte como representante oficial em vários congressos e conferências médicas, tanto no Brasil, como em Uruguai e Argentina.

6 Raul Pilla nasceu em Porto Alegre, em 1892. Diplomou-se pela Faculdade de Medicina de Porto Alegre em 1916, onde atuou como Catedrático de Fisiologia.

7 Chefe do Serviço Médico Escolar da Prefeitura do Rio de Janeiro. Relatório apresentado ao Diretor Geral da Instrução Pública Municipal em 1931.

${ }^{8}$ Oscar Fontenelle, médico higienista de destaque no cenário nacional da época.

9 Pedagogo e filósofo norte-americano nascido em 1859 e falecido em 1952.

${ }^{10}$ Outros autores da educação também são referidos pelos médicos nas primeiras décadas do século XX, como, por exemplo, Adolphe Ferrière, Tristão de Ataíde, Anísio Teixeira e Fernando de Azevedo.

${ }^{11}$ Diretor da Inspeção Médico Escolar do Paraná.

${ }^{12}$ Raimundo Gonçalves Vianna nasceu em 1882, em Porto Alegre. Formou-se em Medicina no Rio de Janeiro, em 1907. Na Faculdade de Medicina de Porto Alegre, foi Catedrático de Anatomia e Fisiologia patológicas. Membro da Liga Brasileira de Higiene, atuou na Sociedade de Medicina de Porto Alegre. 
${ }^{13}$ João Carlos Pitta Pinheiro nasceu em 1869 em Porto Alegre, tendo falecido em 1952. Formou-se em Medicina pela Faculdade de Medicina do Rio de Janeiro, em 1892.

${ }^{14}$ Salvador González, médico atuante em Porto Alegre. Sua obra Sugestões médicosociais registra seu pronunciamento em sessão da Sociedade de Medicina de Porto Alegre, quando se instalou um conjunto de discussões com o intuito de estudar as condições em que se realizavam os cursos de cultura física nos estabelecimentos escolares.

${ }^{15}$ Ver maior detalhamento dessas críticas em Stephanou (1999 e 2005).

16 “Conhecer o indivíduo era operar com tipologias que ordenavam a variedade dos fatos observados e medidos de modo a subsumi-los a classificações tidas como derivadas da natureza das coisas. Era enquadrar o indivíduo no tipo e ler nos corpos sinais que uma ciência determinista constituía como índices de normalidade, anormalidade, ou degeneração" (Carvalho, 1997, p. 275).

${ }^{17}$ Essas designações hoje guardam outro sentido na linguagem ordinária.

${ }^{18} \mathrm{O}$ dr. Ygartua refere-se ao livro do colega W. Berardinelli, intitulado Biotipologia: constituição, temperamento e caráter, de 1936.

${ }^{19}$ São referidas as obras de Nicola Pende: Endocrinologia: patologia e clínica (1916), Endocrinologia: patologia e clinica degli organi e secrezione interni (1920), Patología del simpático (1915), La ciencia moderna de la persona humana (s/d).

${ }^{20}$ Apresentada por ocasião do $2^{\circ}$ Congresso Médico Brasileiro Sindicalista, em 01 de julho de 1933.

${ }^{21}$ Segundo Ygartua, as imagens de seu artigo foram extraídas do livro de Berardinelli e referem-se a seu interesse pela Biotipologia.

22 Diretor do Instituto Pestalozzi, Canoas, Rio Grande do Sul.

${ }^{23}$ O Professor Maria Estapé era citado por vários médicos gaúchos, além de Florêncio Ygartua. Desenvolvia atividades como a psiquiatra escolar em Montevidéu, e com ele o dr. Ygartua realizou trabalhos conjuntos e intercâmbios sistemáticos.

${ }^{24}$ Segundo o dr. Moreira, a eufrenia representa o estudo que tem por fim assegurar a boa formação do psiquismo. Das clínicas de eufrenia procede um objetivo construtivo: o aperfeiçoamento do psiquismo, com atuação médico-pedagógica no despertar intelectual da criança (1933b, p. 6-7). 


\section{Referências}

BARRÁN, José Pedro. 1994. Historia de la sensibilidad en el Uruguay. Montevidéu: Ediciones de la Banda Oriental. v. 2: El disciplinamiento (1860-1920). . 1995. Medicina y sociedad en el Uruguay de novecientos. Montevidéu: Ediciones de la Banda Oriental. v. 3: La invención del cuerpo.

CARVALHO, Marta M. C. de. 1997. Quando a história da educação é a história da disciplina e da higienização das pessoas. In: FREITAS, Marcos Cezar de (org.). História social da infância no Brasil. São Paulo: Cortez/USF, p. 269-288.

CASTILHO, Walther. 1928. Moderna concepção da medicina preventiva. Porto Alegre: Oficinas Gráficas da Escola de Engenharia de Porto Alegre.

CLARK, Oscar. 1930. Higiene escolar. A Folha Médica, v. 11, n. 3, p. 61-69. .1931a. Higiene escolar em 1930. A Folha Médica, v. 12, n. 23, p. 268-269.

$.1931 b$. Higiene escolar e medicina preventiva. A Folha Médica, v. 12, n. 34, p. 397-400.

$.1931 c$. Higiene escolar e medicina preventiva. A Folha Médica, v. 12, n. 36, p. 423-430.

ESPÍRITO, Poli Marcelino. 1934. Contribuição para a higiene escolar no Estado do Rio Grande do Sul. Porto Alegre: Globo.

.1940. O novo modelo de ficha médica escolar. Revista do Ensino, v. 3, n. 10, p. 170-173.

.1942a. Discurso de posse da presidência da Sociedade de Higiene e Saúde Pública proferido em 28 de dezembro de 1941. Arquivos do Departamento Estadual de Saúde, v. 3, p. 174-176.

.1942 b. Parecer sobre a organização de um Serviço de Higiene Mental Escolar. Arquivos do Departamento Estadual de Saúde, v. 3, p. 165-167.

FIGUEIREDO, Adayr. 1933. A assistência médica nas escolas. Correio do Povo, Porto Alegre, 24 jun., v. 39, n. 146, p. 3.

FONTENELLE, José P. 1922. O ensino da higiene. A Folha Médica, v. 3, n. 18, p.
142-143. Excerto da memória "Higiene e saúde pública", escrita em 1921 para o Dicionário histórico, geográfico e etnográfico, publicado em comemoração ao centenário da Independência.

.1932. Educação higiênica. A Folha Médica, v. 13, n. 33, p. 387-389.

FOUCAULT, Michel. 1990. Tecnologías del yo y otros textos afines. Barcelona: Siglo Veintiuno.

.1991. História da sexualidade II: o uso dos prazeres. Rio de Janeiro: Graal. 1993. Vigiar e punir: nascimento da prisão. $10^{\mathrm{a}}$ ed. Petrópolis: Vozes. .1995. A arqueologia do saber. $4^{\mathrm{a}}$ ed. Rio de Janeiro: Forense Universitária.

GONZÁLEZ, Salvador. 1934. Sugestões médico-sociais. Arquivos Rio-Grandenses de Medicina, v. 13, n. 4, p. 182-186.

LARBECK, Emilio K. 1916. A defesa da saúde pública no Rio Grande do Sul. Porto Alegre: Oficinas Gráficas de Ildefonso Robles.

.1934. Contribuição para a higiene escolar no Estado do Rio Grande do Sul. Porto Alegre: Globo.

LENTINO, José. 1930. Algumas considerações em torno do problema da sifilis em São Paulo. São Paulo: Mercúrio.

LIMA, Nísia T.; HOCHMAN, Gilberto. 1996. Condenado pela raça, absolvido pela medicina: o Brasil descoberto pelo movimento sanitarista da Primeira República. In: MAIO, Marcos C.; SANTOS, Ricardo V. (orgs.). Raça, ciência e sociedade. Rio de Janeiro: Fiocruz/CCBB, p. 23-40.

LUPI, Borba.1939. Assistência e preservação da infância contra a tuberculose na idade escolar. Arquivos Rio-Grandenses de Medicina, v. 18, n. 4, p. 163-174.

MACEDO, José P. 1932a. A verminose no meio escolar. Revista Médica do Paraná, v. 1, n. 2, p. 107-109.

.1932b. O Curso de Educação Sanitária da Inspeção Médica Escolar do Paraná. Revista Médica do Paraná, v. 1, n. 3, p. 123-125.

.1932c. Cantinas escolares. Revista Médica do Paraná, v. 1, n. 6, p. 231-236. 
1933. O médico nas escolas. Revista Médica do Paraná, v. 2, n. 7, p. 213-226.

MELLO, Fernando F. de. 1937. Higiene escolar. A Folha Médica, v. 18, n. 14, p. 222-223.

MOREIRA, Raul. 1933a. Padrões de boa saúde na criança (lactente, pré-escolar e escolar). Arquivos Rio-Grandenses de Medicina, v. 12, n. 8, 9-10, p. 421-434.

.1933b. Higiene mental da criança. (Tema Oficial) Conferência Nacional de Proteção à Infância. Porto Alegre: Globo.

.1935. Sobre o ensino da puericultura nas escolas. Revista dos Cursos, v. 21, n. 21, p. 121-128.

PILLA, Raul. 1938. A concepção fisiológica da medicina. Anais da Faculdade de Medicina de Porto Alegre, v. 1, n. 1, p. 67-85. Preleção por ocasião da Abertura dos Cursos, 06 mar. 1937.

PITTA PINHEIRO, João. 1929. O curso de educação sanitária. Egatea, v. 14, n. 3, p. 127-132.

.1930. Inspeção médico-escolar. $O A r$ chivo Médico, v. 9, n. 8, p. 124-126.

1944. Sociedade Humanitária Padre

Cacique. Relatório aos cidadãos membros do Conselho Administrativo da Sociedade Humanitária Padre Cacique, 20 jan. 1944. (Mimeo.).

STEPHANOU, Maria. 1999. Tratar e educar: discursos médicos nas primeiras décadas do século XX. Tese de doutorado, Porto Alegre: Faculdade de Educação, Universidade Federal do Rio Grande do Sul, 2 v. .2005. Discursos médicos e a educação sanitária na escola brasileira. In: STEPHANOU, Maria; BASTOS, Maria Helena C. História e memórias da educação no Brasil-Vol. III-Séc. XX. Petrópolis: Vozes, p. 142 -164.

TOTTA, Mário. 1940. Um ponto de higiene escolar. Revista do Ensino, v. 2, n. 7, p. 271-272.

.1952. Obras, conferências, crônicas e contos, cartas e bilhetes, discursos, memórias. Porto Alegre: Selbach.

VIANNA, Gonçalves. 1926. Os rumos da medicina social: a nobre campanha da Liga Brasileira de Higiene Mental. Revista dos Cursos, v. 12, n. 12, p. 67-79.

YGARTUA, Florêncio. 1933a. O médico nas escolas. Revista dos Cursos, v. 19, n. 19, p. 212-229.

.1933b. A inspeção médico-escolar. Correio do Povo, Porto Alegre, 04 jul., v. 39 , n. 154, p. 3.

.1933c. O médico nas escolas. Correio do Povo, Porto Alegre, 24 ago., v. 39, n. 197, p. 5.

$.1933 d$. O médico nas escolas. Correio do Povo, Porto Alegre, 31 ago., v. 39, n. 203, p. 5.

Recebido em 02/11/2005

Aprovado em 22/12/2005 